DE

DE GRUYTER

OPEN

U

Marzena Stor ${ }^{11}$

Uniwersytet Ekonomiczny we Wrocławiu

Teresa Kupczyk ${ }^{12}$

Wyższa Szkoła Handlowa we Wrocławiu
Journal of Intercultural Management

Vol. 7, No. 2, June 2015, pp. 49-74

DOI 10.1515/joim-2015-0010

\title{
Differences in Competency Management - Comparative Analysis between Polish, Spanish, and Austrian Business Practices
}

\begin{abstract}
The main goal of the article is to present some differences in the practice of competency management, perceived as a part of human resources management, that were identified in the empirical research conducted in three countries, that is Poland, Spain, and Austria. Our research is placed within cross-cultural HRM and comparative HRM, that together with corporate-international HRM make three theoretical and research streams within international human resources management (IHRM). This is because on one side, the analysis of the research data covers comparison of competency management systems and practices both at the organizational and national level in different countries, but on the other side, we make an attempt to discuss the possible influence of national culture on identified differences.
\end{abstract}

Key words: competency management, cultural dimensions, cross-cultural HRM, comparative HRM

\section{INTRODUCTION}

In today's competitive and constantly changing business environment competency management $(\mathrm{CM})$ is considered as a tool that may help companies to

\footnotetext{
${ }^{8}$ marzena.stor@wp.pl

12 teresa.kupczyk@handlowa.eu
} 
respond to competitive business challenges. The main assumption is that with the implementation of a competency framework, employees are seen as the main source of value added as well as the main source of competitive advantage.

In this context the main goal of the article is to present some differences in the practice of $\mathrm{CM}$ that were identified in the empirical research conducted in three countries, that is Poland, Spain, and Austria. Our research is placed within crosscultural HRM and comparative HRM, as two theoretical and research streams within international human resources management (IHRM). This is because on one side, the analysis of the research data covers comparison of CM systems and practices both at the organizational and national level in different countries, but on the other side, we make an attempt to discuss the possible influence of national culture on identified differences.

The findings presented in this article make a part of some bigger research project cofounded by the Erasmus+ Program of the European Union. The main goal of the empirical research was to identify, analyze and diagnose business practices in the scope of CM in selected European countries. However, in this article we focus only on content analyses of CM, its configurations with other HRM components (subfunctions), as well as its connections with the business strategic objectives.

In our project we assume that competency management is as a part of human resources management which itself is a part of company management. To make these assumptions clear it is necessary to explain the basic terminology and definitions adopted in this research project, as to mention competency, competency management, and human resources management.

\section{THE TERM AND SCOPE OF COMPETENCY MANAGEMENT}

In the literature there is no common agreement on how to definite competency and how it differs from competence as these two terms are sometimes used interchangeably and sometimes as two words of different meaning. This is the final conclusion that comes from our broad literature review, covering the internationally recognized publications produced within the last 35 years and resulting in a broad array of various definitions mostly quoted in the pertinent literature ${ }^{13}$.

One of the reasons is that competency and competence are objects of interests of different scientific disciplines [Gonsalvez, Calvert 2014, p. 201]. Another important reason lies in the fact that competencies are an object of interest in different sectors, both private and public, and within these both in the USA and Europe as well [Page et al 2005]. Thus, competencies are discussed from national, sectorial

${ }^{13}$ See the selected examples: Boyatzis 1982, p. 16, Guion 1991, p. 335, Spencer \& Spencer 1993, p. 4, Woodruffe 1993, p. 29, Rowe 1995, p. 12, Mirabile 1997, p. 21, Green 1999, p. 5, The Manager... 2001, p. 1, Buford \& Lindner 2002, p. 3, Jackson, Schuler 2003, Gangani et al 2006, p. 127, Draganidis, Mentzas 2006, p. 53, Teodorescu 2006, pp. 27-29, Ljungquist 2007, p. 396, Guidelines .... 2011, p. 33, Antczak 2013, Kupczyk 2013, p. 25, Stor 2014, p. 15. 
or organizational perspectives [Chapman, Lovell 2006]. Moreover, some authors focus on inputs and outputs connected with competencies and consider them in the context of individual or corporate requirements [Hoffmann 1999, p. 283]. So far, different stakeholders have been also interested in competencies, as to mention: psychologists, management theorists, human resource managers, educationists, politicians, trade unions, employer groups etc. [Burgoyne after: Hoffmann 1999, p. 275].

Apart from that, for many years there have been some differences between American and British English as well [Moore et al 2002]. The dominant approach in the USA has been to employ a person-oriented job analysis (e.g. behavioral event interviews) to identify those characteristics distinguishing superior performers. The competencies are thus expressed as skills, personal characteristics or behaviors. The dominant approach in the UK is to use a tasks-oriented job analysis technique called functional analysis to identify the necessary roles, tasks and duties of the occupation, rather than the skills of successful job holders [Cheng et al 2003, p. 530].

All this brings to a conclusion that depending on a scientific perspective that somebody employs the definitions of competency and competence are formulated respectively. At the same time the similar phenomena are observed in business practice, meaning various definitions of competency and competence resulting from different practical and implementive perspective.

In our research project we assume, taking the organizational perspective, that competency means the skills, knowledge, personal characteristics, and behaviors needed to effectively perform a role (work) in the organization and help the business meet its strategic objectives. And to make the distinction between competence and competency clear, we also assume that competence (plural - competences) means a potential ability or a potential capability to function in a given situation while competency (plural-competencies) focuses on the actual performance in a situation. Thus, competences make employees capable of fulfilling their job responsibilities and their competencies make them perform their jobs as expected. In other words, competencies are determined by comparing where the employees are now with established performance standards developed in the work environment according to their roles and setting based on standard (template) competences. That means an employee needs competence before he or she can expect to achieve competency (Stor, 2014a:15). In our understanding these definitions are broad enough to help us grasp all the different practices within CM that we want to include in our empirical research.

When it comes to defining competency management we encounter the same kinds of problems as those within the scope of competency and competence meaning, a huge variety of definitions used in theory and business practice ${ }^{14}$. That's

${ }^{14}$ See the selected example: Homer 2001, p. 59, Gangani et al 2006, p. 131, Capece, Bazzica 2013, pp. 40-44, Rausch et al 2002, Van Assen 2000, pp. 142-143, Draganidis, Mentzas 2006, p. 51, 
why in this research we've decided to define competency management $(\mathbf{C M})$ as a set of activities performed in an organization and oriented toward identification, acquirement, development and maintenance of such employees' competencies that enable the company reach its strategic goals.

There are also different approaches to whether $\mathrm{CM}$ is a part of something bigger, like generally understood company management, human resources management, human resources development, knowledge management or whether it is a separate issue from all those mentioned here. But in our understanding, in a context of a company it can't be considered as something existing in a vacuum. That's why in our research project it is perceived as a part of human resources management ${ }^{15}$ (HRM) which itself is a part of company management.

In today's competitive and constantly changing business environment, CM may help managers and human resource professionals improve the skills portfolio and the efficiency level of their workforce to match changing market demands, in order to respond to competitive business challenges. Ranging from staffing (recruitment, selection and placement), retention, performance appraisal, motivating, compensation, promotion, talent and high-potential programs, dismissals, and training and development to organizational strategic planning, competencies are used today in a wide range of functions within human resources management. The main assumption is that with the implementation of a competency framework, employees are seen as the main source of value added as well as the main source of competitive advantage.

But as competencies are expected to bring the company its competitive edge through some value added it is justified to employ some more modern approach to HRM, that is the strategic one. In this context strategic human resources management (SHRM) covers these decisions and actions which refer to employees, give direction for personnel operations in their long run and are of substantial significance to organization success [Listwan 2000, p. 14]. The aim of SHRM is to provide the directions and means of utilizing human resources in pursuing company's goals achievement [Listwan 2010, p. 60].

\section{THE STRATEGIC CONNECTIONS: COMPETENCIES, HRM AND BUSINESS GOALS}

What the authors emphasize in the literature is that competency-based HRM enables the company to fulfill its business needs. This should be valuable for those companies whose goals are to [Dubois, Rothwell 2004, pp. 53-45; Gangani et al

Rodriguez et al 2002, p. 310, Ngo et al 2014, Sienkiewicz 2013, p. 10, Kupczyk 2014, p. 25, Filipowicz 2014.

${ }^{15} \mathrm{HRM}$ is defined as a set of activities concerning people and tending to achieve organizational objectives and fulfill employees' needs [Listwan 1986, p. 19]. Its main objective is to make the company gain its competitive edge and enable the organization to succeed through its employees. 
2006, p. 127; Soderquist et al 2010, p. 326: Oleksyn, 2010, p. 40; Sutton, Watson 2013, p. 1026; Sienkiewicz, Trawińska-Konador 2013, p. 7]:

- acquire the high level of efficiency and effectiveness,

- increase competitive advantage,

- improve the quality of products and/or services,

- adjust organizational and employee competencies to changing needs,

- improve production efficiency and productivity,

- prepare the organization to further growth and development,

- facilitate change implementation in organizational culture,

- reach better results in relationships with customers,

- be more flexible and more responsive to the external and internal dynamically changing requirements,

- improve financial results,

- integrate particular HRM subfunctions, procedures, method, techniques, and instruments,

- adjust HRM procedures to company mission, vision, values, strategies and business goals.

In this handling CM feeds and supports both HRM and company management simultaneously. It is perceived as a common ground for business and HRM strategies and substrategies. This is how a company can gain, maintain and develop its competitive edge thanks to people treated as a [Stor 2012]:

- resource which is valuable (possesses some value), rare (possesses certain unique features), inimitable (imperfectly imitable), and nonsubstitutable (imperfectly substitutable), but also as a

- capital asset which is a source of present and future incomes, and through investment made in this asset it can bring an expected return in the form of benefits or value added inputs.

This makes at least a partial explanation why competency-based practices utilize a competency framework to align the strategic imperatives of an organization with its key HRM programs. By applying a systematic framework to evaluate employee competencies, an organization may be able to build an ongoing snapshot of the overall knowledge and skills portfolio of its workforce. An organization can utilize this information to perform organizational assessment and may be able to improve its HRM programs, including talent acquisition practices, performance management system, training and development tools, employee retention practices, and organization development strategies [Gangani et al 2006, p. 127].

So far the conclusion is that basing company management and HRM on key competencies and further making the strategies of these two types of management coherent is expected to influence positively on sustainable competitive advantage of a company. The practice may go two ways. A company may firstly decide to 
determine its business goals. Then it may identify the competencies necessary to reach these goals. And finally it may establish a framework for competency-based HRM in which different subfunctions of HRM are founded on competencies and all this is to contribute to the realization of business goals. But a company may also decide to go the other way which is to build its business strategies after the key human competencies and organizational capabilities are identified. In this case it is not strategies that determine competencies needs but it is competencies that determine the strategies. When this first task is completed then the company may establish its competency-based HRM system to acquire, maintain and develop its human competencies (and company's capabilities) in pursuing its business goals and competitive advantage. These strategic connections between competencies and HRM and business strategies make the basic foundations for CM itself.

\section{THE GOALS AND PROCESS OF COMPETENCY MANAGEMENT}

The research shows that organizations adopt CM for similar reasons (listed in decreasing order of frequency): to enhance performance, to integrate HR processes, to align behavior with corporate values, selection, development, and career pathing [Stone 2013, p. 335]. And the discussions that accompanies these developments over the meaning and goals of $\mathrm{CM}$ leads to a conclusion that depending on the specific needs of a company, its HRM system as well as people themselves, CM finds a lot of different uses which serve selected goals. They range from more general to more precise, from more business-oriented to more human capital-oriented, from more organizational to more individual. But the main goal that CM is to support is to enable the company succeed, to gain and maintain its competitive advantage and to prepare the organization for any alterations and changes that appear in its external and internal environment.

And as about the CM process itself, as the name implies, it is a sequence of activities that one needs to perform to manage competencies. In this scope the literature provides various examples of both theoretical approaches ${ }^{16}$ and practical developments applied in business practice ${ }^{17}$. The theoretical concepts lead to a general conclusion that the $\mathrm{CM}$ process can be perceived from narrower or broader perspective depending whether the authors focus on tying competencies directly with strategic company goals, business strategies and associated HRM strategies or whether they focus on company functioning performance, business processes,

\footnotetext{
${ }^{16}$ See for example: Dubois, Rothwell 2004, p. 46, Gangani et al 2006, pp. 130-131, Mansfield 1996, p. 7, Capece, Bazzica, 2013, p. 43; Draganidis, Mentzas 2006, p. 55, Yang et al 2006, p. 68, Suchodolski 2014.

${ }^{17}$ See for example: The 3M Company [Alldredge, Nilan 2000]; American Medical Systems [Gangani et al 2006], A Chilean construction company [Serpell, Ferrad 2007]; A joint project of UKPIA \& Cogent in petroleum industry [Guidelines for..., 2011]; Automobile Club d'Italia [Capaldo et al 2006].
} 
project requirements, job demands, tasks characteristics etc. All this determines the number of particular steps followed in $\mathrm{CM}$, the content of these stages, their internal and external connections as well as expected results. And regarding business practices, CM systems are developed from broader contexts, like industry, or from narrower one, meaning company's. And similarly to theoretical conceptions they are applied to improve organizational functioning, ensuring business goals and strategies realization mostly by tying $\mathrm{CM}$ with particular subfunctions of human resources management ${ }^{18}$.

\section{COMPETENCY MANAGEMENT IN COMPARATIVE HRM}

Our research, as said in the introductory part of this article, is placed within comparative HRM and cross-cultural HRM, which together with corporateinternational HRM make three theoretical and research streams within international human resources management (IHRM) ${ }^{19}$ (see Table 1). This is because in the empirical part of our research we intend to compare the CM systems at the organizational level in different countries, as well as discuss some possible influences of national culture on identified differences.

${ }^{18}$ All these are usually supported by IT solution and software. About the role of IT tools in HRM development see: Antczak, 2014.

${ }^{19}$ IHRM alone dates back to the end of the 1970s of the previous century [De Cieri et al. 2003]. Initially, the IHRM literature focused mainly on managing expatriates [see: Perlmutter 1969; Tung 1981; Mendenhall Oddoi 1985]. Simultaneously, one could differentiate publications entirely devoted to the research on cross-cultural problems (see Hofstede, 1980 and next; Laurent, 1986) or mostly interested in comparative HRM [see: Brewster et al. 1996]. As with time more and more publications on international business strategies appeared [see: Bartlett, Ghoshal 1989 and next: Porter 1986, Prahalad, Doz 1987], HRM in MNCs aroused more interests as well. And this is how the three theoretical and research streams mentioned before set apart within IHRM, that is corporateinternational HRM, cross-cultural HRM, and comparative HRM [cf. Boxall 1995, p.9; Schuler 2000, p. 240; Clark et al. 2000, p. 8; Sparrow et al. 2003, p. 3; Keating, Thompson 2003, p. 2, Stor 2011], although some kind of convergence in these three fields is observable as the years pass [cf. Budhwar, Sparrow 2002]. To explain why, it is enough to say that international business partnerships concluded by MNCs (multinational companies) or entering into different types of international joint ventures by these companies make both internal and external HRM environment more complicated, and thus imposing a necessity of more holistic but at the same time more detail approach to HRM issues. This results in operating on the overlap of those three theoretical and research streams perceived as disjunctive. 
Table 1. Tripartition of basic theoretical and research streams in IHRM

\begin{tabular}{|l|l|l|}
\hline Corporate-international HRM & Cross-cultural HRM & Comparative HRM \\
\hline Refers to HRM practices in & Deals with the & Covers comparison of HRM \\
different types of MNCs. & influence of cultural & systems and practices both \\
The authors are generally & differences on HRM & at the organizational and \\
interested in identifying the & practices. & national level in different \\
differences in HRM between & The authors are mostly & countries. \\
particular MNCs. & interested in different & The authors intention is to \\
The research projects & characteristics of HRM & identify the differences in \\
cover differences at various & resulting from national & HRM practices between \\
organizational levels (e.g. & culture. & particular countries. \\
HQs, local subsidiary) and & These characteristics \\
with regard to different & Such comparison may \\
subfunctions of HRM. & include not only & include some comprehensive \\
personnel systems, & approach to HRM or \\
functions, programs & just focus on some of its \\
subfunctions.
\end{tabular}

Source: Stor M. (2014), Reconceptualizing Strategic International Human Resources Management in the Pursuit of MNC Sustainable Competitive Advantage, "Human Resource Management", No 6, Issue 101, p. 12.; Stor M. (2011), Strategiczne miedzynarodowe zarzadzanie zasobami ludzkimi, Wydawnictwo Uniwersytetu Ekonomicznego we Wrocławiu, Wrocław, p. 94.

A brief review of the actual state of the art in a field of comparative HRM suggests that not much research has been devoted so far to CM in business companies due to identify its similarities and differences in country's context. Much more research concentrated on public sector. A good example in this scope, among many others, is S. Op de Beeck's study. In her research she focused on CM at the national level of government. Her final research report gave an overview of current practices in the management of competencies in the public sector. The examined countries included Australia, Austria, Belgium, Canada, Denmark, France, Japan, Korea, the Netherlands, the United Kingdom, and the United States [Op de Beeck 2010]. Some other researchers exhibit interest in educational frameworks. Here an example makes T. Weigel et al who reviewed how four European countries: England, Germany, France and the Netherlands use the concept of competence in the process of developing vocational education and training [Weigel et al 2007]. When it comes to business organizations most comparative research covers only selected issues within CM, paying rather no attention to its more comprehensive or holistic view. For example, although S. Filippov and G. Duysters in their research examined patterns of competence-building in foreign subsidiaries located in new member states of the European Union, they were interested in how subsidiaries accumulate knowledge and competences from interaction with their environment than in employee competencies and their management [Filippov, Duysters 2011]. 
The last research case worth mentioning refers to J. Mühlbacher et al who examined the individual competencies of almost 300 top and middle managers in the Czech Republic, Hungary and Slovenia, and compared the different sets of competencies and interpreted them according to the given economic situation in these countries [Mühlbacher et al 2013]. Of course, there is a huge number of other research projects in the field being discussed, but together with the examples provided here all this suggests that there is a research gap that needs fulfilling.

\section{THE EMPIRICAL RESEARCH METHODICS}

The findings presented in this article make a part of some bigger research project cofounded by the Erasmus+ Program of the European Union entitled Agile-Based Competency Management. The main goal of the empirical research was to identify, analyze and diagnose business practices in the scope of competency management in selected European countries. In this context the main goal of the article is to present some differences in the practice of $\mathrm{CM}$, perceived as a part of human resources management, that were identified in the empirical research conducted in three countries, that is Poland, Spain, and Austria. The general focus is on:

- content analyses of CM,

- its configurations with other HRM components (subfunctions),

- its connections with the business strategic objectives.

The main research problem, that the authors of the article intend to solve, results from the preliminary literature findings, as a summary partly discussed in the sections above. In consequence, from the scientific point of view we asked the following research question: What is the current standing of competency management in business practice of Polish, Spanish and Austrian companies and what are, if any, the main differences in this scope?

Furthermore, as a result of the initially accomplished conceptual settlements, the main research problem was disaggregated into the following research problems and questions of much detail character:

1. What are the goals of CM?

2. How it is connected with other subfunctions of HRM?

3. What does CM cover?

4. What, if any, are the strategic connections with company management and/or individual and business performance?

The population of the subject under research made the companies of different size and business profiles. The key requirement to be included in the research was that a company should exhibit any kind of $\mathrm{CM}$ advancement. It is about the companies that realize somehow the activities within CM.

The research project bases both on qualitative and quantitative methods of research. Firstly, in the preparation phase of the research the project team members 
conducted interviews in about 6 selected companies (the major selection criteria: relatively high advancement of $\mathrm{CM}$ ) and with 4 trainers/consultants (the major selection criteria: relatively long and rich experience with providing services for companies within $\mathrm{CM}$ ) in order to gain some additional information about the phenomena under study. Next the research team carried out a pilot survey in about 10 companies and with 6 trainers/consultants to verify the research tool. The final research sample that we refer to in this article was composed in $65 \%$ of the Polish companies, in 16\% of Spanish, and 19\% of Austrian. The number and structure of respondents is presented in Table 2.

Table 2. The structure of the research sample

\begin{tabular}{|c|c|c|c|c|c|c|}
\hline \multirow{2}{*}{ COUNTRY } & \multicolumn{2}{|c|}{ INTERVIEWS } & \multicolumn{2}{c|}{ PILOT STUDY } & \multicolumn{2}{c|}{$\begin{array}{c}\text { PROPER } \\
\text { RESEARCH }\end{array}$} \\
\cline { 2 - 7 } & $\begin{array}{c}\text { Number of } \\
\text { companies }\end{array}$ & $\begin{array}{c}\text { Number of } \\
\text { trainers } \\
\text { consultants }\end{array}$ & $\begin{array}{c}\text { Number of } \\
\text { companies }\end{array}$ & $\begin{array}{c}\text { Number of } \\
\text { trainers } \\
\text { /consultants }\end{array}$ & $\begin{array}{c}\text { Number of } \\
\text { companies }\end{array}$ & $\begin{array}{c}\% \text { of } \\
\text { companies }\end{array}$ \\
\hline Poland & 4 & 2 & 6 & 4 & 93 & 65 \\
\hline Spain & 1 & 1 & 2 & 1 & 22 & 16 \\
\hline Austria & 1 & 1 & 2 & 1 & 26 & 19 \\
\hline Altogether & 6 & 4 & 10 & 6 & 141 & 100 \\
\hline
\end{tabular}

Source: own empirical research.

Furthermore, in addition to the analysis of the primary and secondary data (various types of the company's documents, including those provided by the company in a paper or electronic form as well as those available in the Internet, including the websites of the companies), the main research technique was survey applied in local languages (Polish, Spanish, Austrian) plus in English. in the three countries. The surveys were performed by the authors of this article in cooperation with two training and consulting companies from Poland, that is Profes and e-peers, one training and consulting company from Spain, meaning Hominem Challenge, and a nonprofit research association from Austria operating under the name of The Multidisciplinary European Research Institute Graz (MERIG). Using the survey the data were collected in the following ways:

- CATI (computer aided telephone interview) - a telephone surveying in which the interviewer sitting in front of a computer screen follows a script provided by a software application,

- CAWI (computer aided Web interview) - the interviewees access the survey questionnaire in the Internet at the dedicated website ${ }^{20}$ and complete this online

${ }^{20}$ The interactive survey questionnaire was available In English at http://survey.merig.eu/index. php/175655/lang-en, in Polish at http://survey.merig.eu/index.php/175655/lang-pl, in Austrian at http://survey.merig.eu/index.php/175655/lang-at, and in Spanish at http://survey.merig.eu/index. php/175655/lang-es. 
- CASI (computer-aided self-interview) - an electronic questionnaire sent to the respondents by an electronic mail,

- CAPI (computer aided personal interview) - a direct interview in which an interviewer uses a portable computer to enter data directly via a keyboard,

- standard pencil \& paper mode - the respondents complete the paper version of the survey given out by the researcher.

Depending on the availability and preferences of the respondents, the most appropriate way of data collection was chosen. The purpose of this was to adjust to the interviewees in such a way as to increase the chances of encouraging them to participate in the research.

To analyze the collected data we used both descriptive statistical method, enabling to describe the research sample and then to make conclusions about the whole population, as well as interpretative methods. For that reason we had to take some theoretical and contextual assumptions. However, in this article we refer only to some cultural dimensions making some broader but possibly influential context on CM in each country under study. Having in mind all the criticism toward both G. Hofstede's and F. Trompenaars \& C. Hampden-Turner's research projects - unfortunately due to the publishing limitations there is no space here to provide some comments on it - we decided to characterize the national and organizational context of Polish, Spanish and Austrian companies referring the research findings on culture received by the mentioned authors. As shown in Figure 12 we used 6 dimensions by $\mathrm{G}$. Hofstede and as presented in Figure 2 only 4 selected dimensions from F. Trompenaars \& C. Hampden-Turner's research.

Figure 1. Cultural dimensions of Poland, Spain, and Austria in G. Hofstede's research

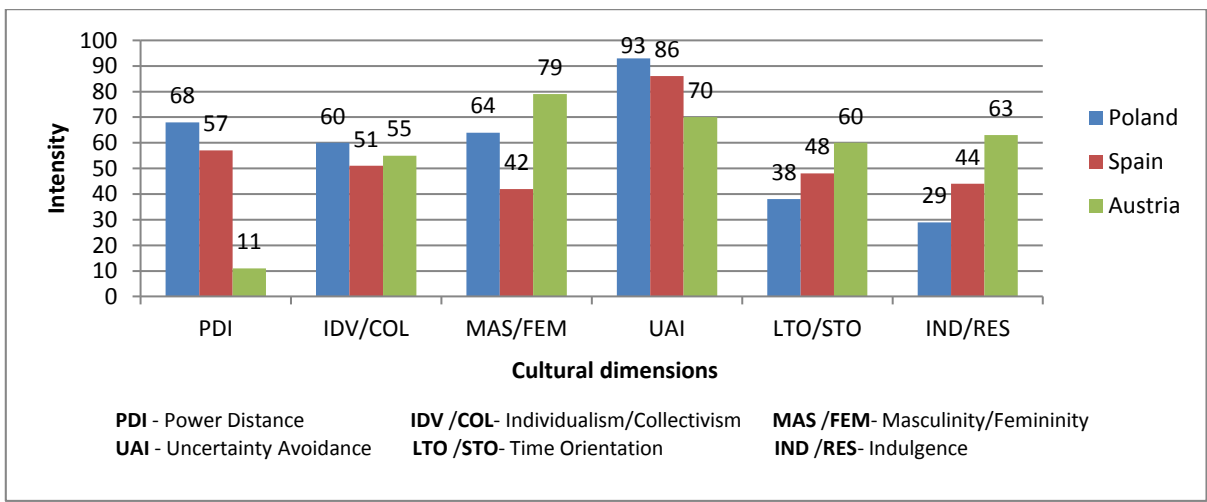

Source: (Hofstede, Hofstede, 2005 and the next editions)

Although both types of the research are well-known, it is worth reminding that the scale used in the G. Hofstede's research denotes intensity of a cultural dimensions 
and runs from 0 to 100 with 50 as a midlevel ${ }^{21}$, whereas the numbers presented in $\mathrm{F}$. Trompenaars \& C. Hampden-Turner's research ${ }^{22}$ refer to the frequency of answers given by the respondents and classified as a particular dimension. Anyway, as about the Hofstede's research Poland gets the highest score PDI, IDV, and UAI. Austrian scores are the highest in MAS, LTO, and IND, and none of the Spanish scores is the highest.

${ }^{21}$ The G. Hofstede's cultural dimensions are [Hofstede, Hofstede 2005]:

- $\quad$ Power distance (PDI) - the extent to which the less powerful members of institutions and organizations within a country expect and accept that power is distributed unequally.

- Individualism vs. collectivism (IDV/COL) - the degree of interdependence a society maintains among its members. In individualist societies people are supposed to look after themselves and their direct family only. In collectivist societies people belong to 'in-groups' that take care of them in exchange for loyalty.

- Masculinity vs. femininity (MAS/FEM) - the extent to which a society is driven by competition, achievement and success (high score - masculinity) or stands for a preference for cooperation, modesty, caring for the weak and quality of life (femininity).

- Uncertainty avoidance (UAI) - the extent to which the members of a culture feel threatened by ambiguous or unknown situations. A high score means that countries maintain rigid codes of belief and behavior (e.g. written rules and formal situations) and are intolerant of unorthodox behavior and ideas. Weak UAI societies maintain a more relaxed attitude in which practice counts more than principles.

- Long-term orientation vs. short-time orientation (LTO/STO) - long-term orientation stands for the fostering of virtues oriented toward future rewards - in particular, perseverance and thrift. Its opposite pole, short-term orientation, stands for the fostering of virtues related to the past and present - in particular, respect for tradition, preservation of "face", and fulfilling social obligations.

- Indulgence vs. restrain (IND/RES) - the extent to which members of a society try to control their desires and impulses. Whereas indulgent societies have a tendency to allow relatively free gratification of basic and natural human desires related to enjoying life and having fun, restrained societies have a conviction that such gratification needs to be curbed and regulated by strict norms.

${ }^{22}$ The F. Trompenaars \& C. Hampden-Turner's referred to in this article are [Trompenaars, Hampden-Turner 1997]:

- Universalism vs. particularism (UNI/PAR) - the universalist approach says that what is good and right can be defined and always applies. In particularist cultures far greater attention is given to the obligations of relationships and unique circumstances.

- Neutrality vs. emotionality (NEU/EMO) - in the neutrality following societies the nature of interactions is objective and detached, and business relationships are typically instrumental whereas in other societies business is perceived as human affair and thus expressing emotions is quite normal and acceptable.

- $\quad$ Specific vs. diffuse (SPC/DIF) - when the whole person is involved in a business relationship there is a real and personal contact (diffuse), instead of the specific relationship prescribed by a contract.

- Inner-directed control vs. outer-directed control (IND/OUD) - in the first of these orientations culture tends to identify with mechanisms; that is, the organization is conceived of as a machine that obeys the will of its operators. The second tends to see an organization as itself a product of nature, owing its development to the nutrients in its environment and to a favorable ecological balance. 
Figure 2. Cultural dimensions of Poland, Spain, and Austria in Trompenaars \& Hampden-Turner's research

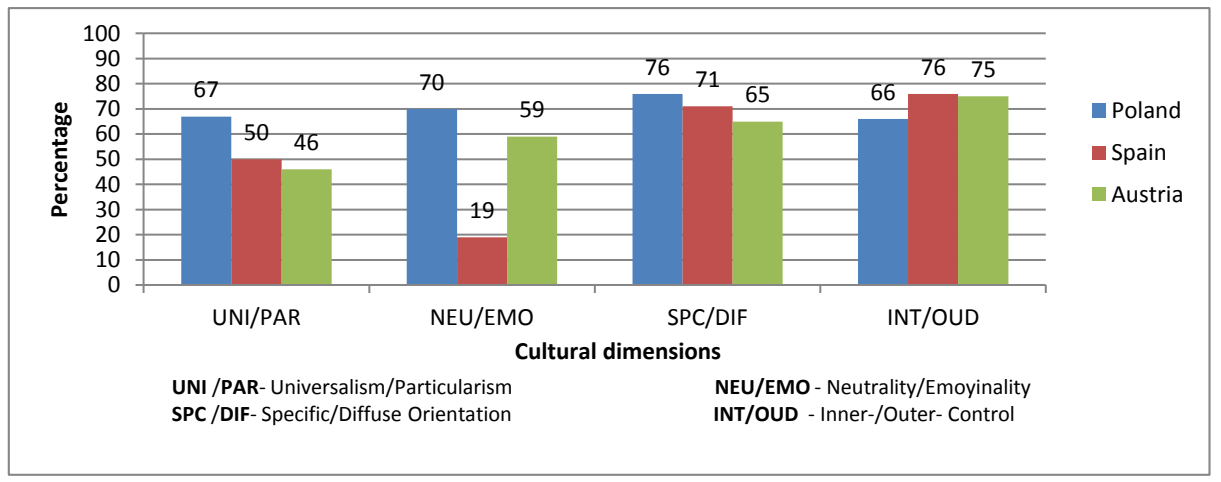

Source: Trompenaars, Hampden-Turner 1997.

And with regard to F. Trompenaars \& C. Hampden-Turner's research, the highest scores in UNI, NEU, and SPC belong to Poland. Spain received the highest score in INT. And none of the Austrian scores is the highest, although it's score in INT is only one percentage point lower than Spanish.

\section{THE EMPIRICAL RESEARCH FINDINGS}

Before undertaking any kind of activity one of the fundamental questions we ask within management is about the goal(s) we intend to realize. We asked our respondents about the goals of CM in their companies (see Figure 3). In Poland the biggest percentage of responses referred to such goals as designing tailored training and developmental programs (56\%), conducting employee performance appraisal (53\%), and managing employee careers (48\%). In Spain most respondents chose the goals connected with personnel recruitment and selection processes $(64 \%)$, employee performance appraisal (59\%), and career management (46\%). In Austria it was personnel recruitment and selection processes (77\%), design tailored training and developmental programs (73\%), and employee performance appraisal (62\%) that gained the highest percentage share in all responses. At the same time the least popular goals in Poland concerned selection of university students/young graduates for job placement $(18 \%)$, succession planning $(19 \%)$, and talent management $(25 \%)$. In Spain the least popular goals were talent management (5\%), succession planning $(14 \%)$, and selection of university students/young graduates for job placement $(19 \%)$. In Austria the smallest percentage of responses were connected with such goals as designing and managing compensation system (27\%) and selection of university students/young graduates for job placement (31\%). In general terms, in Austrian companies CM serves many more goals and is connected with more 
HRM subfunctions than in Polish and Spanish firms. That's why even the smallest percentage of Austrian responses is on average much higher than the smallest percentages in the other two countries. Analyzing the data we can also observe that there are similar proportions between particular choices of responses in Poland and Austria. Furthermore, both in Spain and Austria personnel recruitment and selection processes come first in their goal-oriented popularity of CM. And both in Poland and Spain employee performance appraisal is on the second position among the responses with highest frequency.

Figure 3. The goals of competency management

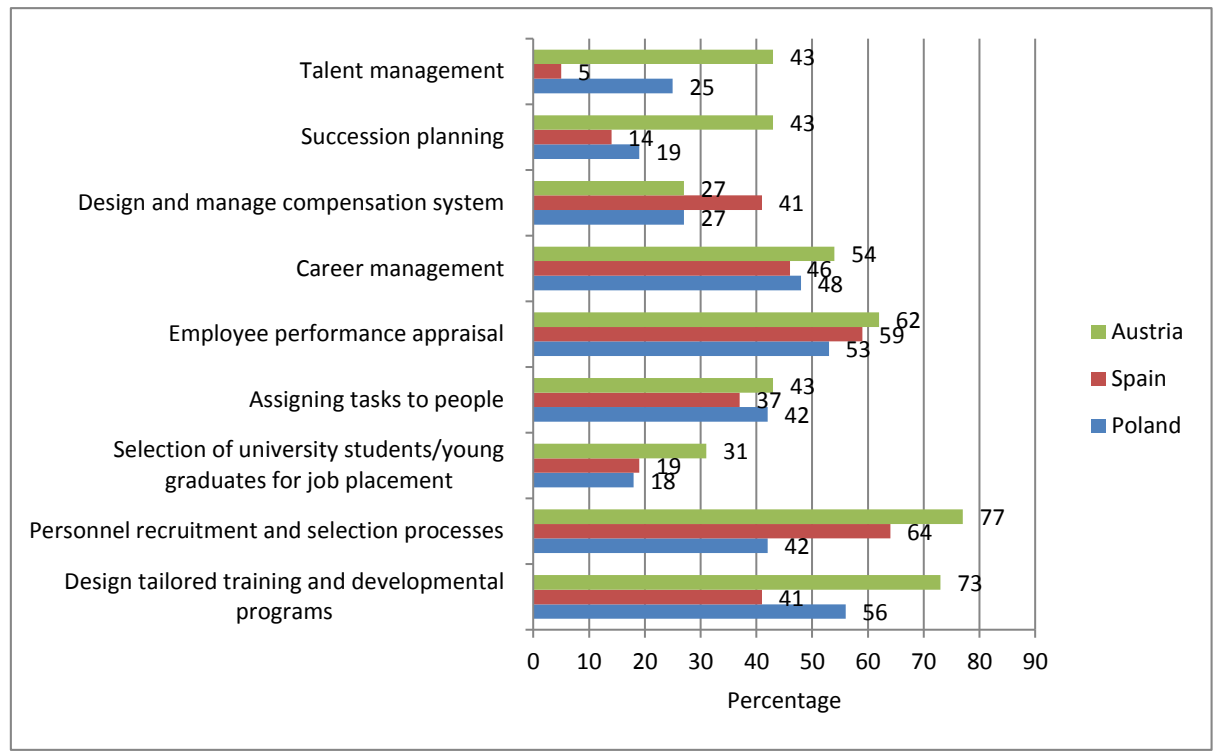

Source: own empirical research.

During the implementation process of $\mathrm{CM}$ the companies involved different subjects with different frequency. The data collected in this range are presented in Figure 4. In each country the biggest percentage of those involved in the implementation of CM make HR managers (in Poland - 46\%, in Spain - 69\%, in Austria - 73\%) and HR specialist (in Poland - 37\%, in Spain - 55\%, in Austria - 43\%), and the smallest one make external consultants $(19 \%, 32 \%$, and $20 \%$ in Poland, Spain, and Austria respectively. The data also suggests that in Poland there are probably the least diverse implementing teams and probably the smallest in the number of their members. But line (31\%) and middle managers $(28 \%)$ are engaged with nearly the same frequency as in Austria (31\% and 35\% respectively). What is specific for Spanish companies is that they engage the biggest percentage of HR specialists (55\%), line managers (50\%), and external consultants $(32 \%)$ in the whole 
research sample. And probably their implementing teams are the most diverse and the biggest in the number of their members. In Austria the biggest percentage of subjects involved in the implementation process of CM make top managers $(62 \%)$ and HR managers (73\%). It also seems that the higher the organizational level and the more expertise knowledge demanded the more involvement of HR managers and top managers in Austrian teams with comparison to the Polish and Spanish practices.

\section{Figure 4. Subjects involved in the implementation process of competency} management

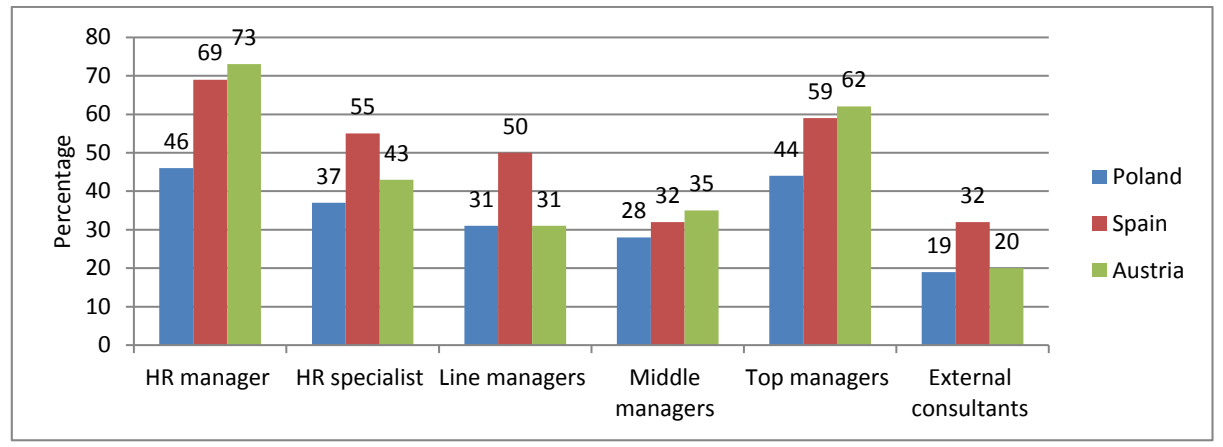

Source: own empirical research.

As about the methods of competency identification we observe very diverse proportions between particular choices in each country (see Figure 5). In Poland the most frequent methods being used are direct observations (56\%), selfevaluation of the employees (51\%), and group discussions (35\%), whereas evidence of exercise questionnaire $(12 \%)$ and working sessions with experts $(15 \%)$ are of the lowest frequency. In Spain the most popular methods are working sessions with experts (41\%), open interviews (37\%), and job analysis questionnaire $(32 \%)$, and the least popular are evidence of exercise questionnaire $(5 \%)$ and behavioral event interview (14\%). In Austria the most popular are direct observations (54\%), and the second place is occupied ex aequo by open interviews, working sessions with experts, and self-evaluation of the employees - each method receiving $43 \%$ of indications. At the same time of the lowest interest are group discussions (33\%). All this leads to a conclusion that both in Poland and Austria the most popular methods of competency identification are direct observations and self-evaluation of the employees. Moreover, it looks as it is Austria in which the companies use the most diverse methods in their business practice. 
Figure 5. Methods of competency identification

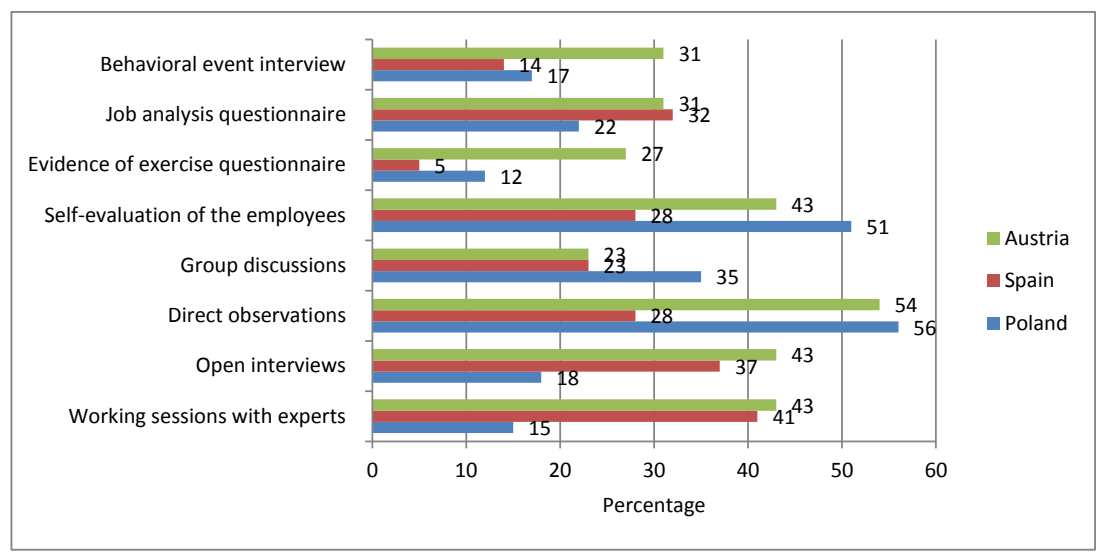

Source: own empirical research.

When rating the complexity and/or proficiency levels of the competencies the companies may take different approaches (see Figure 6). Our research findings suggest that in each country rating the linkage of the competencies to organizational goals, objectives or strategies makes the highest percentage of approaches. Within this about half of the Austrian companies made this choice. It also took place in about $40 \%$ of the Spanish companies and in about $30 \%$ of the Polish ones. The choice of the response referring to rating the extent to which the competency distinguishes high performing employees from average employees is as follows (in descending order): the Polish companies - 22\%; Spanish - 19\%, and Austrian - 4\%. Furthermore, only in Spain there are no ties between rating the importance of the competencies and their future importance but at the same time there's nearly equal interest in it both in Poland and Austria.

Figure 6. Approaches to rating the complexity/proficiency levels of competencies

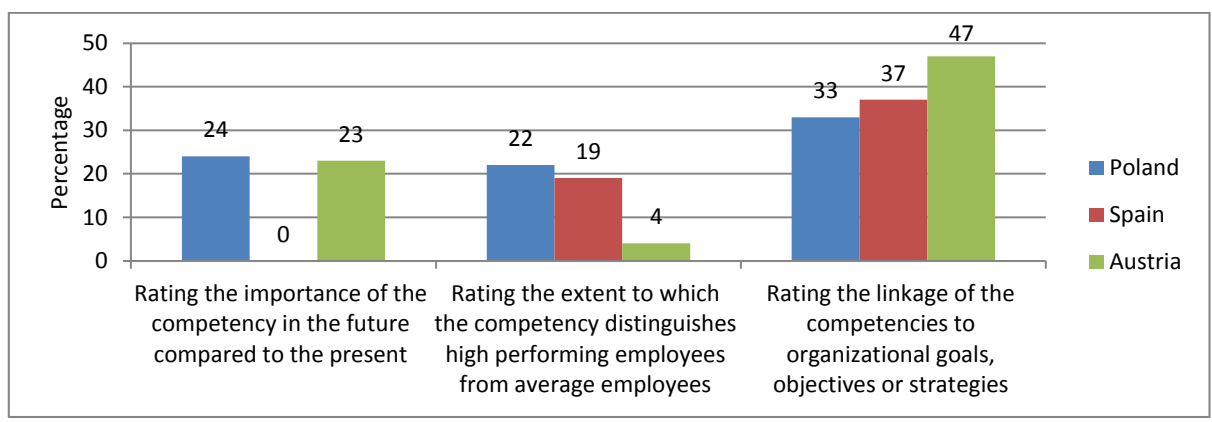

Source: own empirical research. 
Apart from competency identification methods the companies also use different methods of competency assessment. As shown in Figure 7, in the Polish companies the biggest percentage of the all methods being used make observation (47\%), analysis of personnel documents (35\%), and performance results $(32 \%)$, and among those of the smallest percentage are expert opinions (7\%), workshops $(9 \%)$, and situational tests $(11 \%)$. None of the companies reported using repertory grid analysis $(0 \%)$. More than half of the Spanish companies prefer interviews $(55 \%)$, and about one third of them make use of observation (32\%), performance results $(32 \%)$, and $360^{\circ}$ feedback (28\%). The least preferable are workshops $(5 \%)$, expert opinions ( $9 \%$ ), and situational tests (14\%). And like in Poland, none of the Spanish companies uses repertory grid analysis $(0 \%)$. In Austria about half of the companies apply interviews (54\%), observation (50\%), critical incidents interview (31\%), and performance results $(31 \%)$. At the same time repertory grid analysis $(4 \%)$, expert opinions $(12 \%)$, and workshops $(20 \%)$ have the smallest percentage share among all assessment methods used in this country. All in all, the most popular both in Spain and Austria are interviews, and both in Poland and Austria - observations. We can also observe nearly the same percentage of performance results in all countries. In the whole sample of companies, regardless of their national origin, the least popular is repertory grid analysis. It is only Austria in which $4 \%$ of companies uses this method but in the other two countries no company has been interested in this method so far. And everywhere there is rather low interest in expert opinions, workshops, and situational tests.

Figure 7. Methods of competency assessment

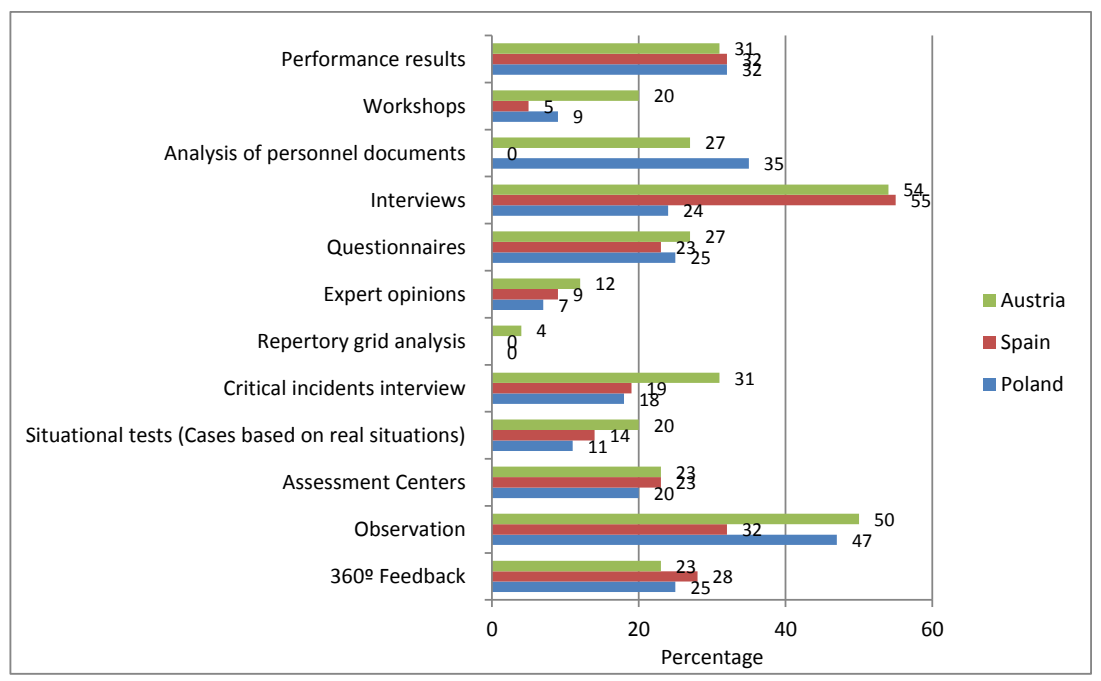

Source: own empirical research. 
To develop competencies the companies use various methods of employee training \& development (see Figure 8). In this cope in Poland the most popular are training programs $(60 \%)$, self-learning $\&$ self-development (48\%), and coaching $(42 \%)$. In Spain the most preferable are coaching $(69 \%)$, outdoor activities (59\%), and mentoring (55\%). And in Austria those of the highest frequency are coaching (73\%), outdoor activities (62\%), and mentoring (43\%). As about the methods which are the least popular in Poland we find outdoor activities (7\%) and blended learning $(13 \%)$. In Spain and Austria rather none of the methods is of the lowest interest. And it is only self-learning and self-development that gain the lowest percentage of indications (i.e. 20\%) in Austria. Generally, we can notice lot of similarities between Spanish and Austrian responses in the range of their proportion between particular choices, as to mention the same order of the most popular methods of employee training \& development. Furthermore, coaching is present in each country but in Spain and Austria it is the most frequent method while in Poland it is on the third place. Moreover, while outdoor activities are the second choice among the most popular methods both in Spain and Austria, they are the least popular in Poland.

Figure 8. Methods used in employee training \& development processes

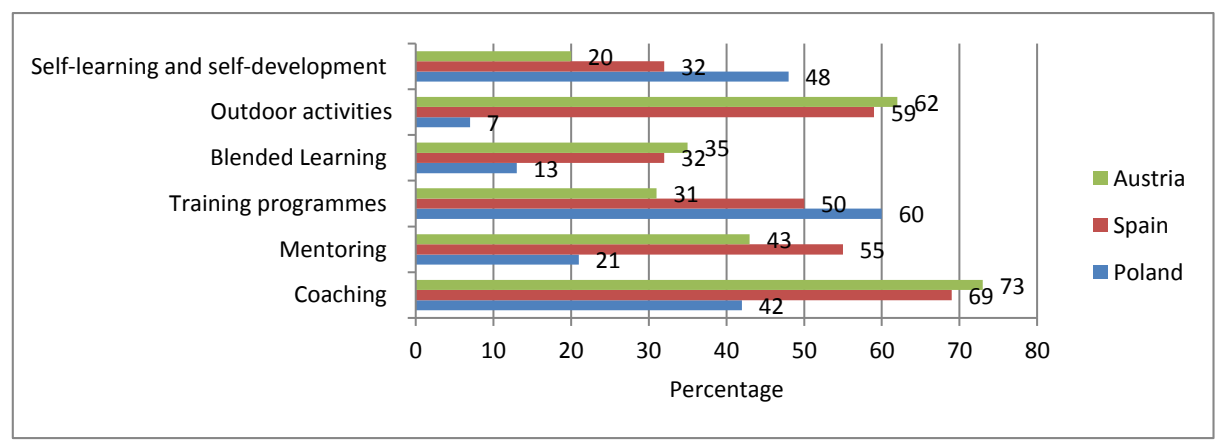

Source: Own empirical research

\section{SOME POSSIBLE CULTURAL INTERPRETATIONS OF THE RESEARCH FINDINGS}

The goals of competency management seem to be the same in each country but not all of them exhibit the same frequency of strategic connections with HRM subfunctions. In Austrian companies CM serves many more goals and is connected with more HRM subfunctions than in Polish and Spanish firms. What may partly explain this phenomenon is the coexistence of four cultural dimensions in Australian society: inner-directed control (INT), indulgence (IND), high uncertainty avoidance (UAI), and midlevel universalism (UNI/PAR). The INT 
societies perceive the organizations as machines that obey the will of its operators. And because the operators (employees) are allowed to strive for different needs and desires (IND), the companies structure and formalize their connections between $\mathrm{CM}$ and HRM in various fields to make clear what needs and desires and in what way can be met in a company (UAI). Moreover, Austrian companies with their midlevel score in UNI are both task and people-oriented and as such they need to balance both the requirements of the employees and the business. In this way the more connections between CM and HRM subfunctions and associated goals, the less uncertainty among the employees what is expected from them and the less ambiguity what the company and its management are to do to assure the company of its proper functioning. Austria is also the country with the highest frequency of ties between $\mathrm{CM}$ and succession planning. This may be explained by its long-term orientation (LTO) which results in a pragmatic approach to the future events and willingness to be ready to face these events successfully. The LTO dimension is probably also the reason that stands behind the lowest frequency of succession planning in Spanish companies. In Spain people like to live in the moment without a great concern about the future. This is also visible in the Spanish approach to rating the complexity and/or proficiency levels of competency. According to the research data the Spanish companies don't rate the importance of the competencies in the future compared to the present.

It is also Spain that has the lowest frequency connection between talent management, as one of HRM subfunctions, and CM. The probable explanation is that Spain is a collective society in which promoting individuals without appreciating their relations with others may act against the communitarian spirit. That's why career management is on average more popular. Poland with comparison to Spain is an individualistic country (IDV), and is more individualistic than Austria. Together with high universalism (UNI) and high uncertainty avoidance (UAI), all these may explain why the most preferable connection between CM and HRM makes designing tailored training and development programs, whereas in the other two countries number one is personnel recruitment and selection processes. In the high UNI societies a company is perceived as a system designed to perform functions and tasks in an efficient way and people are hired and paid to perform these functions and tasks. That's way the Polish companies focus more on task accomplishing and well adjusted and structured training $\&$ development programs (UAI) that suit their individual employees' needs as well as the companies' needs (IDV). It is mostly to ensure that the employees will have the proper competencies in a proper time. At the same time in Spain they assume that the functioning of the organization depends more on social relations than on task performance (more particularism than universalism) and in Austria they try to balance these two things. This can make them more focus on recruitment and selection because it is how they can control the social types of competencies they expect from the potential employees. 
In each of the countries under research $\mathrm{CM}$ covered such activities as assigning subjects (calling up teams) to deal with CM, competency identification, competency assessment, and competency development. The research findings lead to a conclusion that during the implementation process of $\mathrm{CM}$ the most diverse teams and probably the biggest in the number of their members are called up in the Spanish companies, whereas the Polish companies seem to involve the least diverse and the smallest. What can make the reason of the Spanish practice is that its society is rather collectivistic (COL), particularistic (PAR), and feminine (FEM). In this way the more people with different backgrounds are involved, the greater attention can be given to the obligations of various relationships and unique circumstances. Moreover, the more representatives of various company's groups involved, the higher the feeling of belonginess to in-groups and the higher the loyalty to the company and its developments. With regard to the Polish companies two cultural dimensions seem to explain their preferences. On one side, it is masculine (MAS), thus people focus more on tasks than relationships. On the other side, when relationships in a company are considered then they are specific but not diffuse (SPC). It means that in business setting when people are invited to cooperate on something they are predominantly asked to join the team because of their expertise than because of a need to build up the social ties alone. It doesn't mean that social relations are not important at all but they are not the major drive. However, it is not only about the people that invite others to cooperate. From the perspective of those who are invited their participation mostly depends on what they consider to be their own business. When the task doesn't result from their contract and they feel it's none of their business they may be unwilling to cooperate.

Masculinity (MAS), but this time together with neutrality (NEU), may also stand behind the Polish and Austrian choices within the range of competency identification methods. In their business practice direct observations and self-evaluations of the employees are of the highest frequency. It may be so because of the nature of interactions which are supposed to be objective and detached from individual emotions (in contrast to the Spanish culture). And probably these two methods are considered to be the best in collecting the objective information in the competency identification process. They don't demand much interpersonal interactions which usually influence somehow on the information being collected as people exert some mutual impact on each other when they interact. An observer just focuses on gathering the data to complete his or her identification task, like an employee who focuses on providing the data to complete his or her self-reporting task.

As about the methods of competency assessment the Polish companies again prefer those that demand less interpersonal interactions, meaning observations and analysis of personnel documents. Because it is a country of high power distance (PDI) the most such observations are performed by the managers who are entitled 
to conduct competency assessment of their subordinates. At the same time Poland is characterized by high uncertainty avoidance (UAI) and this is why the assessors may prefer to base their judgments rather on written and formal documents than on interviews which are preferable in Spain and Austria. Although these two countries also exhibit high UAI, this cultural dimension coexists with more particularistic (PAR) and indulgence (IND) tendencies and hence more interpersonal interactions are expected. These interactions can help the employees to explain their success or failure in competency development through open communication in Austria (low PDI) and through expressing emotions (EMO) in Spain.

Some other differences are visible with regard to the methods of employee training \& development. Those demanding more interpersonal interactions and based on social support, like coaching, mentoring and outdoor activities, are very popular in Spain and Austria, whereas those requiring more individual efforts and based on individual strain expected by the organization are preferable in Poland. Supposedly, there are two cultural dimensions that differentiate business practices here, that is individualism vs. collectivism and indulgence vs. restrain. In the Polish individualistic (IDV) and restrained society (RES) - in contrast to Austrian and Spanish - the emphasis is on rewards and outcomes that should be accompanied by a neglect of support mechanisms for employees and little orientation toward people. Individualism together with restrain are associated with a concern for task and not with support for employees. Work is centered around individuals and not groups. Consequently, even training \& development practices may be predicted as associated with lower levels of support. Those that need support are perceived as weak and this meets rather negative reactions.

\section{THE FINAL CONCLUSIONS}

The main goal of the article seems to be realized. Some differences within the practice of competency management between the countries under research were identified and these differences may result from the existing cultural differences. However, expanding the formulated conclusions on the whole population wouldn't be valid because of the selection, structure and size of the research sample. The primary limitations of this study are mostly connected with the last feature. Originally, we planned to base our research on a comparable size of sample from each country (50 companies from each country) but finally it appeared to be unsuccessful. The reason was probably rather short time in which the research was realized according to the restrictions imposed by the EU project. It influenced negatively on a capability to conduct comparative analyses. Hence, some further research on much bigger and comparable samples is necessary.

Certain imperfections are also visible in the context of measurement scales that were used, adopted terminology or identification of cultural differences in the 
countries under study. In the case of the last ones it's worth trying to select those which play the key role and submit them to the analysis with regard to their impact on competency management. Nevertheless, it's necessary to emphasize that such undertaking will demand to collate complex terminological and methodological issues. Summarizing we can say that an attempt to draw up some model depictions of relations between $\mathrm{CM}$ with cultural dimensions basing on the conducted research would be premature and groundless. Despite all these deficiencies mentioned above the conducted research has some cognitive value, especially that this field of knowledge and practice has been poorly recognized so far and this was confirmed in the literature review. Our research findings and formulated conclusions can make a linchpin for the future research. Anyway, they should be treated exclusively as a starting point to determine the directions of the future research. But they may also support culturally diverse organizations in their CM improvement and development.

Apart from all the above limitations the final conclusion is that we can't exclude the cultural influence on $\mathrm{CM}$ developments in companies from the research. The significance of this issue will increase in the future in the context of high internalization of companies and their human resources as well as global dimension of economy. Therefore future theoretical and empirical exploration in this scope is indispensable. It would facilitate monitoring the situation, formulating the views and improving the research methodics.

\section{References}

Alldredge M.E., Nilan K.J. (2000), 3M's leadership competency model: an internally developed solution, "Human Resources Management", Vo. 39. No 2.

Antczak Z. (2013), Kompetencje pracowników oraz zapotrzebowanie na nie w przysžtości (foresigbt) [in:] Kapitat ludzki w strukturach wirtualno-sieciowych. Nowe role pracowników i menedżerów wiedzy, (ed.) Z. Antczak, Difin, Warszawa.

Antczak Z. (2014), Wpływ narzęlzi informatycznych na kierunki ewolucji funkcji personalnej w przedsiebiorstwach w Polsce w XXI wieku, „Informatyka Ekonomiczna”, Uniwersytet Ekonomiczny we Wrocławiu, nr 2 (32), Wrocław.

Bartlett C.A., Ghoshal S. (1989), Managing Across Boundaries: The Transnational Solution. Harvard Business School, Boston.

Boxall P. (1995), Building the Theory of Comparative HRM, "Human Resource Management", Vol. 5, No 5.

Boyatzis R.E. (1982), The competent manager. The model for effective performance, John Wiley \& Sons, Inc., New York.

Brewster C., Tregaskis O., Hegewisch A., Mayne L.. (1996), Comparative Research in Human Resource Management: a Review and a example, "International Journal of Human Resource Management", Vol. 7, No 3. 
Budhwar P.S., Sparrow P.R. (2002), An Integrative Framework for Understanding Cross-National Human Resource Practices, "Human Resource Management Review”, Vol. 12, No 7.

Buford J.A.Jr., Lindner J.R. (2002), Human resource management in local government: Concepts and applications for students and practitioners, Southwestern, Cincinnati.

Capaldo G., Iandoli L., Zollo G. (2006), A situationalist perspective to competency management, "Human Resources Management", Vol. 45, No. 3.

Capece G., Bazzica P. (2013), A practical proposal for a "competence plan fulfillment". Key performance indication, "Knowledge and Process management", Vol. 20, No, 1.

Chapman J.A., Lovell G. (2006), The competency model of hospitality service: why it doesn't deliver", "International Journal of Contemporary Hospitality Management", Vol. 18, Issue 1.

Cheng M.I., Dainty, A.R.J. Moore D.R. (2003), The differing faces of managerial competency in Britain and America, "Journal of Management Development", Vol. 22, Issue 6.

Clark T., Grant D., Heijltjes M. (2000), Researching Comparative and International Human Resource Management. Key Challenges and Contributions, "International Studies of Management \& Organization”. Vol. 29, No 4.

De Cieri H., Hutchings K., Fenwick M. (2003), International Human Resource Management: Bridging the Pedagogy-Practice Gap [in:] IHRM: Exploring the Mosaic, Developing the Discipline. Full Papers of the $7 \mathrm{t}^{\mathrm{h}}$ Conference on International Human Resource Management. Interesource Group Ltd. Publishing. Limerick, Ireland.

Draganidis F., Mentzas G. (2006), Competency based management: a review of systems and approaches, "Information Management \& Computer Security”, Vol. 14, No. 1.

Dubois D.D., Rothwell W.J. (2004), Competency-Based Human Resource Management, DavisBlack Publishing. Palo Alto.

Filipowicz G. (2014), Zarzqdzanie kompetencjami. Perspek.tywa firmowa i osobista, Oficyna a Wolters Kluwer business, Warszawa.

Filippov S., Duysters G. (2011), Competence-building in foreign subsidiaries: The case ofnew EU member states, "Journal of East European Management Studies”, Vol. 16, Issue 4.

Gangani N., McLean G.N., Braden R.A. (2006), A competency-based buman resources development strategy, "Performance Improvement Quarterly", Vol. 19. No 1.

Gonsalvez C.J., Calvert F.L. (2014), Competency-based Models of Supervision: Principles and Applications, Promises and Challenges, "Australian Psychologist", Vol. 49.

Green P.C. (1999), Building robust competencies, Jossey-Bass, San Francisco.

Guidelines for Competency Management Systems for Downstream and Petroleum Sites (2011), Petroleum Industry Association Ltd, published by Cogent.

Guion R.M. (1991), Personnel assessment, selection and placement, Consulting, Psychological Press. Palo Alto.

Hoffmann T.(1999), The meanings of competency, "Journal of European Industrial Training", Vol. 23 Iss 6.

Hofstede G., Hofstede G.J. (2005), Cultures and Organizations. Software of the Mind, McGrawHill, New York. 
Hofstede G. (1980), Culture's Consequences: International Differences in Work-Related Values, Sage Publications. Bevery Hills.

Homer M. (2001), Skills and competency management, "Industrial and Commercial Training", Vol. 33, Issue 2.

Jackson S.E.. Schuler R.S. (2003), Managing Human Resources through Strategic Partnerships, South-Western, Mason, $\mathrm{OH}$.

Keating M., Thompson K. (2003), International Human Resource Management: Overcoming Disciplinary Sectarianism [in:] IHRM: Exploring the Mosaic, Developing the Discipline. Full Papers of the $7 \mathrm{t}^{\mathrm{h}}$ Conference on International Human Resource Management. Interesource Group Ltd. Publishing. Limerick, Ireland.

Kupczyk T. (2013), Relations between management competences and organizational success considering gender issues - research results, "China-USA Business Review”, March, Vol. 12, No 3.

Kupczyk T. (2014), Competencies of management staff in the knowledge-based economy, Wyższa Szkoła Handlowa we Wrocławiu, Wrocław.

Laurent A. (1986), The Cross-Cultural Puzzle of International Human Resource Management, "Human Resource Management”, Vol. 25, No 1.

Listwan T. (1986), Organizacja zarzqdzania kadrami w przedsiębiorstwach pržmystowych, Wydawnictwo Akademii Ekonomicznej we Wrocławiu, Wrocław.

Listwan T. (2000), Præedmiot i znaczenie zarzadzania kadrami [in:] Zarzqdzanie kadrami. Podstawy teoretyczne i ćmiczenia, Wydawnictwo Akademii Ekonomicznej we Wrocławiu, Wrocław.

Listwan T. (2010), Modele i składniki strategicznego zarzadzania kadrami [in:] Zarzqdzanie kadrami, ed. T. Listwan, Wydawnictwo C.H. Beck, Warszawa.

Ljungquist U. (2007), Core competency beyond identification: presentation of a model "Management Decision", Vol. 45, Issue 3.

Mansfield R. (1996), Building competency models: Approaches for HR Professionals, "Human Resource Management”, Spring, Vol. 35, No 1.

Mendenhall M., Oddou G. (1985),The Dimensions of Expatriate Acculturation, "Academy of Management Review", Vol. 10.

Mirabile R.J. (1997), Implementation planning: Key to successful competency strategies, "Human Resource Professional", Vo. 10, No 4.

Moore D.R., Cheng M., Dainty A. (2002), Competence, competency and competencies: performance assessment in organisations, "Work Study", Vol. 51, Issue 6.

Mühlbacher J., Kovač J., Novotny A., Putnová A. (2013), Competency Management in Central Europe: A Comparison of Czech, Hungarian and Slovenian Competency Needs, "Organizacja", Vol. 46, No 5 .

Ngo H., Jiang C.Y., Loi R. (2014), Linking HRM competency to firm performance: an empirical investigation of Chinese firms, "Personnel Review", Vol. 43, Issue 6.

Oleksyn T. (2010), Zarzqdzanie kompetencjami. Teoria i praktyka Oficyna, Warszawa. 
Op de Beeck S. (2010), Managing competencies in government: state of the art practices and issues at stake for the future, Organisation for Economic Co-operation and Development, Public Governance And Territorial Development Directorate Public Governance Committee.

Page E.C., Hood C., Lodge M. (2005), Conclusion: is competency management a passing fad?, "Public Administration", Vol. 83, No. 4.

Perlmutter M.V. (1969), The Tortuous Evolution of the Multinational Corporation, "Columbia Journal of World Business", January/February.

Porter M.E. (1986), Changing Patterns of International Competition, "California Management Review". Vol. 28.

Prahalad C.K., Doz Y. (1987), The Multinational Mission: Balancing Local Demands and Global Vision, The Free Press, New York.

Rausch E., Sherman H., Washbush J.B. (2002), Defining and assessing competencies for competencybased, outcome-focused management development, "Journal of Management Development", Vol. 21, Issue 3.

Rodriguez D., Patel R., Bright A., Gregory D., Gowing M.K. (2002), Developing competency models to promote integrated human resource practices, "Human Resource Management", Fall, Vol. 41, No. 3.

Rowe C. (1995), Clarifying the use of competence and competency models in recruitment, assessment and staff development, "Industrial and Commercial Training", Vol. 27 Issue 11.

Schuler R.S. (2000), The Internationalization of Human Resources Management, "Journal of International Management", Vol. 6, September.

Serpell A., Ferrad X. (2007), A competency-based model for constriction supervisor in developing countries, "Personnel Review", Vol. 36, No. 4.

Sienkiewicz L. (2013), Zarzqdzanie zasobami ludzkimi w oparciu o kompetencje. Perspektywa uczenia siepržz całe życie, Instytut Badań Edukacyjnych, Warszawa.

Sienkiewicz L., Trawińska-Konador K. (2013), Wprowadzenie do ZZL w oparciu o kompetencje w kontekśsie uczenia sie przez cate życie [in:] Zarzqdzanie zasobami ludzkimi w oparciu o kompetencje. Perspektywa uczenia sie przez całe życie, ed. L. Sienkiewicz, Instytut Badań Edukacyjnych, Warszawa.

Soderquist K.E., Papalexandris A., Ioannou G., Prastacos G. (2010), From task-based to competency-based. A typology and process supporting a critical HRM transition, "Personnel Review", Vol. 39, Issue 3.

Sparrow P., Harris H., Brewster C. (2003), Towards a New Model of Globalizing HRM [in:] IHRM: Exploring the Mosaic, Developing the Discipline. Full Papers of the $7 \mathrm{t}^{\mathrm{h}}$ Conference on International Human Resource Management. Interesource Group Ltd. Publishing. Limerick, Ireland.

Spencer L.M. Jr., Spencer S.M. (1993), Competencies at work: Models for superiorperformance, John Wiley \& Sons, New York.

Stone T.H., Webster B.D., Schoonover S. (2013), What Do We Know About Competency Modeling? [in:] "International Journal of Selection and Assessment", September, Vol. 21, No 3. 
Stor M. (2011), Strategiczne miedzynarodowe zarzadzanie zasobami ludzkimi, Wydawnictwo Uniwersytetu Ekonomicznego we Wrocławiu, Wrocław.

Stor M. (2012), Continental frameworks for HRM effectiveness and efficiency in MNCs: European, American, Asian, and African perspectives, "Human Resource Management", Vol 6, No 89.

Stor M. (2014a), Managerial capital as a source of company's competitive advantage [in:] Success in buman resources management. Diversity in human capital management - approaches, methods, tools. Economic and managerial issues, Research papers of Wrocław University of Economics No 349, ed. M. Stor, T. Listwan, Wrocław University of Economics, Wrocław.

Stor M. (2014b), Reconceptualizing Strategic International Human Resources Management in Pursuing Sustainable Competitive Advantage of MNCs, "Human Resource Management", No 6 (10).

Suchodolski A. (2014), Closer or Further? Comparison of Employee Development Trends in Polish and International Companies Operating in Poland [in:] "Edukacja Ekonomistów i Menedżerów. Problemy. Innowacje. Projekty”, Szkoła Główna Handlowa w Warszawie, No 3 (33).

Sutton A., Watson R. (2013), Can competencies at selection predict performance and development needs?, "Journal of Management Development", Vol. 32, Issue 9.

Teodorescu T. (2006), Competence versus competency. What is the difference?, "Performance Improvement", Vol. 45, No. 10, Nov/Dec.

The Manager Competency Model (2001), Hay Acquisition Company I, Inc., Boston.

Trompenaars F., Hampden-Turner C. (1997), Riding the Waves of Culture: Understanding Cultural Diversity in Business, Nicholas Brealey Publishing. London.

Tung R. (1982), Selection and Training of Personnel for Overseas Assignments, "Columbia Journal of World Business", Vol. 23.

Van Assen M.F. (2000), Agile-based competence management: the relation between agile manufacturing and time-based competence management, "International Journal of Agile Management Systems", Vol. 2, No. 2.

Weigel T.M. MulderCollins K. (2007), The concept of competence in the development of vocational education and training in selected EU member states, "Journal of Vocational Education and Training", Vol. 59, No 1.

Woodruffe C. (1993), What Is Meant by a Competency?, "Leadership \& Organization Development Journal", Vol. 14, Issue 1.

Yang B.C., Wu B.E., Shu P.G., Yang M.H. (2006), On establishing the core competency identifying model. A value-activity and process oriented approach, "Industrial Management \& Data Systems", Vol. 106, Issue 1. 